\title{
Leaving Judaism
}

\author{
Lena Roos
}

\section{1 \\ Introduction}

According to halakhah, Jewish law, there are two ways of becoming a Jew: either by being born of a Jewish mother or by converting. Hence, being Jewish does not necessarily involve any particular beliefs or practices. From the point of view of the halakhah there is no way for a Jew to leave Judaism, regardless of $\mathrm{s} /$ he was born a Jew or converted. Although a person may formally and ritually convert to another religion, according to the halakhah s/he remains a Jew (Ben-Sasson et al. 2007: 275). That said, it is clear that there is great variety in how this seemingly clear-cut rule can be interpreted, as will be discussed below. Some of those who have left Judaism and joined religions, identify as adherents of their new faith and no longer see themselves as Jews. Others maintain dual identities, for instance as Jewish Buddhists or Jewish Muslims. Still others claim never to have left Judaism, but are not recognised as Jews by mainstream Judaism, like the Jesus-believing Messianic Jews (Cohn-Sherbok 2000; Kollontai 2004).

\section{$2 \quad$ Key Terms}

In spite of the principle "always a Jew," the many different terms referring to those who have formally left Judaism, either by renouncing Judaism or by joining another religion, show that such individuals have nevertheless been seen as constituting a category of their own, separate from other Jews. The etymologies of these words also indicate various understandings of a person who has left Judaism. Perhaps the most neutral term is mumar, which comes from a root simply meaning "to change." Another frequently used term is meshummad. This is related to the Hebrew word shmad, meaning "forced conversion," "persecution" or even "utter destruction." Hence, a meshummad is a person who has converted under duress, not out of conviction, and could be expected to return to Judaism if given the opportunity (Ben-Sasson et al. 2007: 275). This term is often used, for instance, during the persecutions and forced conversions of the Middle Ages. If a meshummad repents, s/he should be allowed 
back into the Jewish community, although some halakhic authorities require that certain symbolic acts of repentance be performed. These acts might be for instance the confessing of one's sin and repentance of it in the presence of three rabbis, or immersion in a mikveh, a ritual bath, as in the case of converts to Judaism (Ben-Sasson et al. 2007: 276; Endelman 2015: 26).

During the Hellenistic period the Greek term apikoros ("heretic") appears. It is first used in the Mishnah (Sanhedrin 10.1) as one of the groups of Jews who have lost their share in the world to come. The word had two related meanings: 1. One who no longer follows the commandments. 2. One who ridicules the Torah and those who follow the Torah (Rabinowitz 2007: 255-256, for an extensive discussion, see also BT Sanhedrin 99b-100a). Maimonides defines an apikoros as someone who denies prophecy, or revelation, or that God has knowledge of the actions of human beings (Maimonides, Mishneh Torah, Teshuvah $3: 8$ ).

Other terms include kofer ("denier") and poshe'a Yisrael ("transgressor of Israel"; "rebellious Jew") (Ben-Sasson et al. 2007: 275). In the Talmud a kofer is someone who points out contradictions between Biblical texts (BT Sanhedrin $39 \mathrm{a}-\mathrm{b})$. Maimonides defines a kofer as someone who denies the divine inspiration of the Torah or the authority of the oral law, or who claims that the Torah has been superseded (Maimonides, Mishneh Torah, Teshuvah 3:8).

Clearly, however, leaving a religion does not always imply conversion to another. It can also mean ceasing to be religious altogether. Since Judaism is less concerned with faith than practice, in most cases this would signify ceasing to practice Judaism as outlined in the halakhah: keeping kosher, saying the daily prayers, resting on the Sabbath, following the rules of sexual purity and so on. Doing so would not make a person any less Jewish in the eyes of the halakhah, merely sinful as s/he would be failing to follow the commandments. What makes the situation even more complicated in the case of modern Judaism is that the Hebrew adjective dati ("religious") often means specifically Orthodox or ultra-Orthodox. This means that terms commonly used to describe such individuals require a bit of explanation. For instance, the acronym datlash, short for dati lesheavar ("formerly religious") refers to a person who has left (ultra)-Orthodoxy but not necessarily Judaism altogether, desiring rather to practice it according to his/her own understanding. Another term for this is ex-frum, using the Yiddish word frum ("pious," "observant"), which usually refers to (ultra)-Orthodox (Kissileff 2014).

Another expression that can denote those who leave Orthodoxy is yotzim leshe'elah ("those leaving to question"), a term reminiscent of the classical term for those who do the opposite, namely become Orthodox, chozrim bitshuvah ("those returning in repentance") (Shaffir 2000: 271). 
Although both Islam and Christianity prohibit forced conversions, these have occurred in periods of persecution, for instance as during the First Crusade in 1096, or the Almohad invasion of the Iberian Peninsula in the twelfth century. Many of these conversions were, however, temporary, and the forced converts returned to Judaism as soon as possible (Roos 2003, 2006). Yet there were also Jews who converted who remained in their new faith, some of these even becoming famous for trying to convince their former co-religionists to follow them. One famous example is the man known as Hermannus quondam Judaeus ("Hermann, formerly a Jew," a twelfth-century German Jew), an autobiography of whose conversion has been preserved. According to this work, before his conversion Hermann used to have debates on the Hebrew Bible with Christian theologians, but what, in his opinion, does make Jews want to convert to Christianity are the prayers of pious Christian women, the love Christians show to Jews and the good example of righteous Christian living (Roos 2006: 53). Another well-known convert was the Dominican Paul Christian, who delivered a number of forced sermons for Jews in Spain, and who was furthermore the Christian adversary of the Jewish scholar Nachmanides at the famous Barcelona disputation of 1263 (Roos 2015). The thirteenth century was also the period when the Christian church began systematic attempts at converting Jews (Endelman 2015: 27). The sources do not allow of any attempt to quantify the numbers of Jews that converted either to Islam or to Christianity, given that Jewish sources tend to downplay the numbers, and non-Jewish ones to exaggerate them. In addition to that, Jewish rabbinic sources like the Responsa literature tend to deal with particular cases that did not follow standard patterns, and hence called for special attention. It is therefore hard to know how representative such cases are for conversions in general (Cohen 1987: 23).

It is clear that in some settings these "New Christians" remained a separate group, one not considered entirely sincere by the "Old Christians." The most well-known case of this is of course in the Iberian Peninsula, where for generations Jewish converts to Christianity could be suspected of secretly practicing Judaism, and thus might face persecution by the Inquisition. Indeed, in some cases this was true, and it is known that, in Spain and its colonies in the Americas, a number of families who had been subjected to forced conversion maintained Jewish practices, a group in scholarship usually referred to as crypto-Jews (Kunin 2009).

During the Enlightenment, most Christian Enlightenment thinkers were critical of Christian persecution of Jews throughout history. Although Enlightenment thinkers may have contributed to the emancipation of the Jews, this 
did not mean that they had a favourable view of the Jewish religion, which they considered to be equally full of superstition as Christianity, and argued had no place in the life of enlightened persons (Heinemann et al. 2007: 214). Their arguments do not, however, seem to have convinced many Jews to abandon Judaism or religion altogether. In post-Enlightenment Europe, many Jews chose to embrace Christianity as part of assimilating into majority society. Others remained Jews but secularised and non-practicing ones. Some of the converts were motivated by religious conviction, others by other factors. Even so, it is clear that many of them were still regarded as Jews by Christians around them even after converting (Endelman 2015: 12). During certain periods, including the last decades of the nineteenth century, this attitude is related to increased hostility towards Jewish emancipation and integration (Endelman 2015: 101). During this period, the desire to convert could often be linked to age and career choices. The relative rate of conversions differed from region to region, but in general it was mainly the young and those wanting to enter new professionsthe academy, media, civil service, law, the arts-who converted. Those who stayed in the traditional Jewish world of commerce at various levels had little to gain from conversion to Christianity (Endelman 2015: 125). It is impossible to generalise when it comes to gender and conversion. In contexts where women were excluded from many aspects of Jewish life, for instance traditional studies, and were therefore more exposed to the non-Jewish surroundings, they were often more likely to convert. But in middle-class Jewish settings, where the women were less likely to work or socialise outside Jewish circles, they were less likely to convert than men, since they too had less incentive to do so (Endelman 2015: 133-137).

As well as those who converted for religious or pragmatic reasons were those who were influenced by the growing nationalism of the late nineteenth century. The same nationalism that nourished early Zionism also fostered a feeling that in order to be able to embrace Deutschtum, for instance, or Magyar nationalism, one had to become Christian (Endelman 1987: 15).

In the late nineteenth and early twentieth centuries, there were plenty of Christian missionary organisations devoted to converting Jews to Christianity. After the Holocaust many of these have ceased to exist or changed their focus to Jewish-Christian dialogue. Today Christian missionary activity towards Jews is mainly limited to various evangelical/fundamentalist Christian groups, some Messianic Jewish, some not (Endelman 1987: 17-18. See for example Charisma News on evangelizing Jews, McGuire 2015; Chosen People Ministries; The Church's Mission among Jewish People; Light of Zion and One for Israel).

An interesting development since the 196os, especially in the US, is a stream of Westerners that in one way or another have adopted Buddhism, especially 
in the forms of Zen Buddhism. People from Jewish backgrounds are overrepresented in this category and are often referred to as JuBus or JewBus (Jewish Buddhists) (Gez 2011: 45, 52). One of the reasons suggested why Buddhism has proved attractive to Jews dissatisfied with Judaism is that, unlike with Christianity and Islam, Judaism had no previous history of enmity or competing claims with Buddhism (Gez 2011: 56). Another reason may have been that it offered a form of spirituality and an understanding of the nature of the world that was acceptable for post-Holocaust Jews who were asking difficult questions about why God had allowed the Holocaust to happen (Gez 2011: $58 \mathrm{ff}$ ).

One of the problems in gauging the numbers of Jewish adherents of Buddhism is that standard Western surveys presume that a person only belongs to one religious tradition, whereas many of those who taught Buddhism to Westerners in the second half of the twentieth century stressed that their teachings were compatible with affiliation with other religions as well (Gez 2011: 52). In some cases, studying and practicing Buddhism seems to have led to an increased practice of Judaism as well, sometimes at the instigation of the teachers of Buddhism. This is especially interesting as many Jewish Buddhists came from secular background (Gez 2011: 54). What could be perceived as a way of leaving Judaism, can be understood from another perspective as a way of returning to Judaism. Similar patterns can also be found among Jews in the West who has embraced Islam through Sufi movements (Sorgenfrei 2013).

As stated above, however, leaving Judaism does not have to mean joining another religion; it can also mean leaving Orthodoxy or becoming secular. Recently there has been an increase in research into this phenomenon. This movement is not an insignificant one, as is attested by the number of autobiographies of individuals who have chosen this path, the ex-frum or datlashim (Ross 2014; Halberstam 2011). Interestingly, rather than merging into other categories such as progressive or secular Jews, this group seems to maintain a distinct identity, (Blum, 2015). Yehuda Mirsky, a scholar who has studied the group notes: "the difference between Datlashim and ordinary religious defectors is that Datlashim want their children to be Datlashim, too." (Mirsky 2012).

Leaving ultra-Orthodoxy, however, can be a complicated process (Davidman 2014). The men, especially, having concentrated on traditional Jewish subjects in most of their schooling have few skills that would render them employable in the outside world. In addition, these individuals are leaving a community which is very supportive of its members, and may find it difficult to cope on their own. Studies have shown that an added difficulty is that, since even to contemplate leaving Orthodox practice is perceived as a grave sin, often a person having such thoughts finds him/herself without anyone with whom 
to discuss these matters (Shaffir 200o). Hence the support of other datlashim and of organisations such as New York-based Footsteps can be vitally important. Similar organisations include U-vaharta and Hillel in Israel, Mavar and GesherEU in the UK and and Forward in Canada. These provide counselling, peer support, education and career programs to facilitate the adjustment to life outside the ultra-Orthodox community.

Major Controversies and Significant Case Studies

One major controversy in modern times has been how the halakhic authorities should regard the group referred to as "Messianic Jews" or "Hebrew Christians," that is, Jews that believe that Jesus was the Jewish Messiah. This is a heterogeneous category, containing some groups that stand quite close to traditional rabbinic practice, and others, mainly in the US, that are more charismatic and closer to evangelical Christianity (Cohn-Sherbok 2000; Kollontai 2004).

Most Jewish authorities do not recognise Messianic Jews as Jews on various grounds including that Jesus's teachings were contrary to Jewish faith and practices, or that for those who consider his teachings compatible with rabbinic teachings, he was not the Messiah. Another reason is that the Messianic Jews are seen as embracing beliefs that have been used to oppress Jews throughout history, for instance the view that Christians are God's chosen people. A further reason is that Messianic Judaism implies that Judaism is not complete in itself. This animosity towards Messianic Jews has resulted in Orthodox groups putting pressure on authorities to deny Messianic Jews the Right of Return (the right to emigrate to Israel), and in attacks on Messianic Jewish establishments and homes in Israel (Kollontai 2004).

Another reason why the Messianic Jews are controversial is that at least some of the groups actively proselytise among Jews, something that is still very contentious in the Jewish world, because of the long history of the Christian mission to the Jews. In Israel and elsewhere, there are a number of Jewish organisations that work to prevent and counteract missionary activities directed towards Jews and also intermarriage. The oldest is Yad L'achim ("A hand to brothers") founded in 1950. More recently founded is Jews for Judaism. Its name resembles that of Jews for Jesus, one of the most important evangelical Messianic Jewish missionary organisations (Kollontai 2004). One final anti-mission organisation is Outreach Judaism. The activities and resources provided by these organisations testify to the continued effort of various missionary groups to proselytise among Jews and to the perceived need of Jewish organisations to counteract this. 
Another controversial issue in connection with this is intermarriage. In Orthodox Judaism intermarriage is not permitted, and for a Jew to marry a nonJew would thus amount to him/her leaving Judaism. More progressive forms of Judaism have taken a more positive stance on intermarriage. For example, in 2015 the Reconstructionist Rabbinical College decided that it would admit and graduate students who are in interreligious relationships, even rabbinical candidates ("Reconstructionist Give Green Light to Intermarried Rabbinical Students," 2015).

One of the most controversial cases concerning Jewish identity and conversion was the case of Oswald Rufeisen (1922-1998). Rufeisen was born a Jew, but converted to Christianity and subsequently entered the Carmelite order in 1945. Before his conversion he had been a member of the Zionist youth movement, and he clearly retained this connection to the State of Israel, because in 1962 he appealed to the Israel High Court to be granted Israeli citizenship under the Law of Return which grants the right to citizenship to all Jews. Rufeisen (or Brother Daniel, by then) claimed that right as he still considered himself part of the Jewish people, despite having become a Catholic Christian. This longing for the Holy Land was also, he states, the reason why he had chosen a monastic order and a chapter in Israel. His request, however, was refused. The reason given was that although he was still considered a Jew from the point of view of the halakhah, the Law of Return was based not on halakhah but on Jewish national/historical consciousness and the ordinary secular meaning of the term "Jew" as understood by Jews. According to this understanding, a person who had willingly converted to another religion was not a Jew. In addition, recognising Brother Daniel as a Jew would be tantamount to denying the spiritual values that Jews of all ages had died for when they refused to give up their religion (Ben-Sasson et al.: 2007, 273).

In its modern interpretation, the understanding of the Law of Return appears to be based upon the general notion of Jewish identity, rather than halakhic definition of who is a Jew, since children and spouses of Jews, for example, despite not fulfilling the requirements of the halakhah, have still been granted the right of "return" (Lent 2010).

\section{5}

\section{Major Texts}

As stated above, according to the Talmud it is impossible for someone to cease to be a Jew, even if s/he is completely non-practicing and even converts to another religion (BT Sanhedrin 44a). The thirteenth-century sage Nachmanides attributes this to Deuteronomy 29:14 which states that the covenant between 
God and Israel was made "with him that stands here with us today before the Lord our God and also with him that is not with us here today" (Nachmanides ad loc). This also means that a child born of a Jewish mother, even if she has left Judaism, is considered a Jew (Maimonides, Mishneh Torah, Ishut 4:15). A marriage between two apostates or between an apostate and another Jew, if conducted according to the Jewish rite, is considered valid according to halakhah (BT Yevamot 3ob; Shulchan Aruch, Even Ha-ezer 44:9). Even so, the texts suppose that the party who remains within Judaism will prefer to divorce the apostate spouse (Isserles, Moses on Shulchan Aruch, Even Ha-Ezer 140:5; 154:1). All of this applies equally to converts to Judaism (BT Yevamot 48a).

Most of the classical commentaries agree with the position stated above, that a Jewish apostate remains a Jew. This would not be Judaism, however, if there were not dissenting voices. Maimonides, for one, claims that individuals that have left Judaism voluntarily are no longer part of the Jewish people, referring to the verse: "None that go to her repent, nor will they regain the paths of life" (Proverbs 2:19, Maimonides, Mishneh Torah, Hilkhot Mamrim 3:2.). If, however, an apostate is still considered a Jew, then in theory, should s/he at some point choose to return to Judaism, no particular rite would be necessary. Nonetheless, some authorities have required that an apostate confess his sins, repent and promise to follow the halakhah henceforth (Ben-Sasson et al. 2007: 276). The sixteenth-century sage Moses Isserles claimed that returning apostates should undergo a purifying bath in the mikveh, just like converts to Judaism (Isserles on Shulchan Aruch, Yore Deah 268: 12)

Such reasoning even continues into twentieth century Reform Judaism, according to a responsum that stresses that most Jews who convert to Christianity mean no harm to Judaism, being rather concerned with their own interests, such as marrying a Christian or furthering their position in a society with a Christian majority. Although the Jewish community may not have any respect for a person who leaves Judaism, the door should always be open for him or her to return, and if the children of apostates return, no reconversion is required ("Our Attitude to Apostates").

\section{6}

\section{Key Figures}

When we review some of the key Jewish figures who have left Judaism it becomes clear that they fall into various categories. One such category is made up of Jews who joined other religions and became avid proponents of those religions. A good example is the Dominican Paulus Christianus in the thirteenth century, who made use of his Jewish background to argue for the supremacy of 
Christianity from Jewish sources. From the point of view of Orthodox Judaism, some Messianic Jews would also fall into this category - organisations like Jews for Jesus for example - because of their missionary activities towards other Jews. Its founder Moishe Rosen came from an Orthodox Jewish background, and first took an interest in Christianity in order to be able to refute the arguments of his Jewish wife who had become interested in Christianity. Both of them eventually converted and Rosen became a key figure in evangelical circles that evangelised Jews in the 1950s, -6os and -70s before founding his own organisation in 1973. Throughout his life he kept many Jewish customs such as fasting on Yom Kippur and hosting Passover seders (Fox 2010).

Another category contains those who simply left Judaism, embracing other faiths and from then on considered adherents of those religions. Most of these individuals have, quite naturally, gone unnoticed, especially in periods when conversions were common. Others have achieved notoriety. Within this category Shabbetai Zevi (1626-1676) stands out. Shabbetai Zevi was the leader, and designated Messiah, of the largest messianic Jewish movement in the modern era. The movement was deeply influenced by Kabbalah, especially in its Lurianic variant, which originated among the Early Modern Jewish mystics of the town of Safed. A central tenet of this movement was that all Jews were able to contribute to the process of restoration and redemption and thereby of hastening the coming of the Messiah. In 1666 Shabbetai Zevi travelled to Constantinople, apparently with the aim of deposing the sultan. Once there he was imprisoned by the authorities, and while in prison he was presented a choice between death or conversion to Islam. He chose to convert. This was naturally a disappointment to many of his followers, although some of them developed a doctrine that explained how this had all been part of a greater messianic plan (Scholem 2007).

A final category contains those that have formally converted to another religion, but where some disagreement exists as to whether or not they should still be considered Jews. One example from this category is the Catholic monk Oswald Rufeisen discussed above who wanted to claim the Right of Return as a Jew, despite having converted to Christianity. Another case that received international attention was that of the Carmelite nun St Teresa Benedicta of the Cross (1891-1942). Teresa was born into an observant Jewish family and began her life as Edith Stein. Stein pursued an academic career and received a PhD in philosophy. It is said that it was reading of the autobiography of St Teresa of Avila that moved her to convert. After holding various teaching positions, she entered a Carmelite monastery in Cologne. She later transferred to a monastery in Echt in the Netherlands, but even there she was not safe from Nazi antisemitism. In 1942, along with other converted Jews in the Netherlands, she was 
arrested and transferred to a concentration camp. She was executed the same year at the Auschwitz concentration camp. She was canonised by Pope John Paul II in 1998, and is one of the six patron saints of Europe. There was some controversy surrounding this process with critics claiming that she had been martyred because of her Jewish heritage, not because of her Christian faith. The position of the church, however, was that she was executed as a result of the stance taken by the Catholic Church in the Netherlands against Nazi antisemitism, and therefore should be considered a martyr of the church (Popkin 2007).

\section{7}

\section{Conclusion}

Within Judaism there are many different terms that are used to designate what in theory does not exist: a person who has left Judaism. As is often the case when Judaism is compared to Christianity or Islam, for example, Judaism does not fit our notion of what a "religion" should be like. In a society where religious identity ideally is something that is chosen by the individual, Judaism stands out as difficult to enter and, in theory, impossible to leave, in much the same way a person may change his/her nationality but not his/her ethnicity. It is clear that, in comparison with other religions, the status of a person who has "left" Judaism is a complicated issue, in comparison to other religions, due to the fact that the definition of Jewishness is determined not by faith nor by practice, but by a person's lineage. Faith and practice can be abandoned, but lineage remains.

\section{References}

Ben-Sasson, H.H., Perlmann, M., and Dov N. 2007. "Apostasy." In M. Berenbaum and F. Skolnik ed., Encyclopaedia Judaica, Vol. 2. 2nd ed. Detroit: Macmillan Reference USA, 269-277.

Blum, B. 2015. “This Normal Life: In praise of Datlashim." Jerusalem Post, June 4, 2015. At http://www.jpost.com/Opinion/This-Normal-Life-In-praise-of-datlashim-405053. Accessed 6/4/2017.

CCAR: Central Conference of American Rabbis. "Our Attitudes to Apostates." At https://www.ccarnet.org/responsa/mrr-169-175/. Accessed 6/4/2017.

Chosen People Ministries. At https://www.chosenpeople.com/. Accessed 6/4/2017.

The Church's Mission among Jewish People. At http://www.cmj-usa.org/. Accessed $6 / 4 / 2017$. 
Cohen, J. 1987. "The Mentality of the Medieval Jewish Apostate: Peter Alfonsi, Hermann of Cologne, and Pablo Christiani." In T.M. Endelman ed., Jewish Apostasy in the Modern World. New York: Holmes \& Meier, 20-47.

Cohn-Sherbok, D. 200o. Messianic Judaism. London: Cassel.

Davidman, L. 2014. Becoming Un-Orthodox: Stories of Ex-Hasidic Jews. Oxford University Press.

Endelman, T.M. 1987. “Introduction.” In T.M. Endelman ed., Jewish Apostasy in the Modern World. New York: Holmes \& Meier, 1-19.

Endelman, T.M. 2015. Leaving the Jewish Fold. Conversion and Radical Assimilation on Modern Jewish History. Princeton: Princeton UP.

Footsteps. At https://www.footstepsorg.org/. Accessed 6/4/2017.

Forward. At http://forwardorg.org/. Accessed 6/4/2017.

Fox, M. 2010. "Moishe Rosen, 78, dies, Founder of Jews for Jesus." New York Times, May 22, 2010. At https://www.nytimes.com/2010/05/22/us/22rosen.html. Accessed 15/5/2019.

GesherEU. At http://www.geshereu.org.uk/. Accessed 6/4/2017.

Gez, Y. N. 2011. "The Phenomenon of Jewish Buddhists in Light of the History of Jewish Suffering." Nova Religio 15:1, 44-68.

Halberstam, J. 2011. "Lives of the Ex-Haredim." Jewish Ideas Daily, August 2, 2011. At http://www.jidaily.com/03978. Accessed 6/4/2017.

Heinemann, J., Gutmann, J., Poliakov, L., Weissman, P., Hertzberg, A., Toury, J., Harkabi, Y., Eliav, B., Curtis, M., Bauer, Y., Altwarg, H., Lerman, A., Schopflin, J., Spier, H., Schudrich, M.J., and Porat, D. 2007. "Antisemitism." In M. Berenbaum and F. Skolnik, eds, Encyclopaedia Judaica, Vol. 2. 2nd ed. Detroit: Macmillan Reference USA, 206-246.

Hillel. At https://www.hillel.org.il/. Accessed 6/4/2017.

Jews for Judaism. At http://jewsforjudaism.org/. Accessed 6/4/2017.

Kissileff, B. 2014. "Ex-Frum' vs. 'Datlash': Two Very Different Literary Genres." Tablet, February 24, 2014. At http://www.tabletmag.com/scroll/163824/ex-frum-vs-datlash -two-very-different-literary-genres. Accessed 15/4/2017.

Kollontai, P. 2004. "Messianic Jews and Jewish Identity." Journal of Modern Jewish Studies. 3:2, 195-205.

Kunin, S.D. 2009. Juggling Identities. Identity and Authenticity among the Crypto-Jews. New York: Columbia UP.

Lent, D. 2010. "Analysis of the Israeli High Court: Jewish Apostates and the Law of Return." Kol ha-mevaser. At http://www.kolhamevaser.com/2010/og/analysis-of-the -israeli-high-court-jewish-apostates-and-the-law-of-return/. Accessed 13/4/2017.

Light of Zion. At http://lightofzion.org/. Accessed 6/4/2017.

Mavar. At http://mavar.org/. Accessed 6/4/2017. 
McGuire, P. 2015. "Sid Roth: The Key to Evangelizing Jews." At http://www.charis manews.com/opinion/standing-with-israel/50081-the-supernatural-law-of-evange lism-roth-sid. Accessed 6/4/2017.

Mirsky, Y. 2012. "Varieties of Post-Religious Experience." Jewish Ideas Daily, March 21, 2012. At http://www.jewishideasdaily.com/1094/features/varieties-of-post-religiousexperience/. Accessed 6/4/2017.

One for Israel. At https://www.oneforisrael.org/. Accessed 6/4/2017.

Outreach Judaism. At https://outreachjudaism.org/. Accessed 6/4/2017.

Popkin, R.H. 2007. "Edith Stein.” In M. Berenbaum and F. Skolnik eds, Encyclopaedia Judaica, Vol. 19. 2nd ed. Detroit: Macmillan Reference USA, 176.

Rabinowitz, L.I. 2007. “Apikoros.” In M. Berenbaum and F. Skolnik eds, Encyclopaedia Judaica, 2nd ed., vol. 2, Macmillan Reference USA, 255-256.

"Reconstructionist Give Green Light to Intermarried Rabbinical Students." 2015. The Jewish News of Northern California, 2 October, 2015. At http://www.jweekly.com/ 2015/10/02/reconstructionists-give-green-light-to-intermarried-rabbinical-stu dents/. Accessed 6/4/2017.

Roos, L. 2003. "Acknowledge Muhammad and do not choose death": Some attitudes to martyrdom, conversion, and persecution among Jews living under Muslim rule during the eleventh and twelfth centuries. Uppsala: Swedish Science Press.

Roos, L. 2006. "God wants it!": The Ideology of Martyrdom of the Hebrew Crusade Chronicles and its Jewish and Christian Background. Turhout: Brepols.

Roos, L. 2015. "Rhetoric and Religious Heritage." In O.P. Füllenbach and H. Elias eds, Dominikaner und Juden. Personen, Konflikte und Perspektiven vom 13. bis zum 20. Jahrhundert. Quellen und Forschungen zur Geschichte des Dominikanerordens Neue Folge 14. Berlin: De Gruyter, 115-134.

Ross, T. 2014. "How Ex-Frum Memoirs Became New York Publishing's Hottest New Trend." Tablet, January 7, 2014. At http://www.tabletmag.com/jewish-arts-and-cul ture/books/158130/ex-frum-memoirs. Accessed 6/4/2017.

Scholem, G. 2007. “Shabbetai Zevi.” In M. Berenbaum and F. Skolnik eds, Encyclopaedia Judaica, Vol. 18. 2nd ed. Detroit: Macmillan Reference USA, 340-359.

Shaffir, W. 200o. "Movements In and Out of Orthodox Judaism: the Cases of Penitents and the Disaffected." In L.J. Francis and Y.J. Katz eds, Joining and Leaving Religion. Research Perspectives. Leominster: Gracewing, 287-308.

Sorgenfrei, S. 2013. American Dervish:Making Mevlevism in the United States of America. Göteborg. Göteborgs universitet.

Yad L'Achim. At http://yadlachim.org/. Accessed 6/4/2017. 